\title{
Mountain Disasters and Rescue Mechanism in Nepal
}

\author{
Ramesh Vikram Shahi \\ APF Command and Staff College, Nepal \\ rvshahi777@gmail.com
}

\section{Article History}

Received September 30, 2020

Accepted October 21, 2020

Keywords Mountain,

disaster, search and

rescue, mechanism, $A P F$
Corresponding Editor

Ramesh Raj Kunwar

kunwar.dr@gmail.com

\section{Abstract}

Geographically, Nepal is divided into three regions, namely; the Terai, the hills, and the mountains. Nepal is prone to many types of disasters due to the various causes and one of the main causes is its geographic setting. Some disasters and hazards are prevalent to all over the country, some are area specific. Mountain and high altitude hazards are unique in nature and have distinct features and they pose several challenges for the rescue and relief operations. Disasters in mountain regions of Nepal have multi-dimensional effects on human life, property and the environment. The paper analyzes the mountain disasters, their nature and their impacts. It also focuses on the institutional as well as legal arrangements regarding disaster rescue. For this purpose, a qualitative descriptive and analytical method is applied to achieve the desired objectives of the study. This paper depends upon the secondary source of data available in several works of literature; journal articles, books, news articles, government reports, and websites. The paper finds that the frequencies of mountain disasters are low in comparison to other parts of Nepal, but they are diverse and complex. There are institutional and legal mechanisms for disaster risk reduction, but they are not adequate to respond mountain disasterseffectively. All securityagencies along with private sectors involving in mountain search and rescue operationsdonothavesufficientmountain-specificrescueunits, training, and logistics. 


\section{Introduction}

Nepal, due to its geography, geological position, and the impact of climate change, is exposed to the multiple hazards creating multitude of disasters throughout the country claiming large number of lives and significant economic loss every year. Further intensification is done by the unplanned and rapid urbanization, environmental degradation, variations in nature and type of disaster and inadequate understanding of disaster risk management (MoHA 2019).

The Himalayan Region or high mountain region is characterized by inclement climatic and rugged topographic conditions. The Himalayan region of Nepal is one of the most hazard-prone because of its steep terrain, high seismicity, fragile geological formation, and intense and highly variable precipitation, this region is especially vulnerable to GLOF, landslides, avalanches, and earthquakes. Currently, natural hazards in the mountain are increasing in magnitude and frequency, a trend driven partly by climate change. While some of the factors in exposure and vulnerability are physical and environmental, other factors are socioeconomic, such as poverty, human settlement and habitat, lack of preparedness, susceptibility, and adaptive capacity (Nepal DRR Portal, 2020).

Mountain Disasters are not only the threat to the local people and properties, but also to the tourists. More and more groups of people visit the mountainous areas for expedition, trekking, exploration and research workbecause of the curiosity towards nature. With increase in the number of visitors to Nepal especially the adventure enthusiasts, invention of new adventure sports and opening of new areas for tourism activities in the remote areas of the country, the challenges to mitigate the disaster risks have also augmented quantitatively and qualitatively. In recent years, other incidents like high altitude sickness in mountains frequently occur beside natural disasters.

Search and Rescue activities are "part of a complex emergency system that emerges to respond to disasters, which are lifesaving activities during disasters" (Dynes \& Quarantelli, 1980). In Nepal, limited trained personnel from the Security forces namely Nepal Army, Nepal Police and Armed Police Force, Nepal are conducting search and rescue operations. They mobilize in all parts of Nepal as the major responder of disaster rescue but high mountain areas have many challenges for effective search and rescue operations. The Government of Nepal has developed the minimum level SAR capacity from the trained security personnel. In mountain region, security agencies, private helicopter companies and volunteer organizations are carrying out the rescue operations (MoHA, 2017).

The high vulnerability of Nepal to disasters needs the continuous preparedness and planning. Disaster preparedness provides a platform to design effective, realistic and coordinated planning, reduces duplication of efforts and increase the overall effectiveness of National mechanism and response efforts. Disaster preparedness activities embedded with risk reduction measures can prevent disaster situations and also result in saving maximum lives and livelihoods during any disaster situation, enabling the affected population to get back to normalcy within a short time period. Search and rescue activities are an integral part of the preparedness and it is necessary to examine the national capacity and procedures on preparedness and response. 


\section{Review of literature}

John (1980) defined disaster as "a part of the environmental process that is of greater than expected frequency and magnitude and causes major human hardship with significant damage". Generally, a disaster is viewed as "an extreme event that arises when a hazard agent intersects with a social system". Technically, then, disasters are events that take place as part of normal environmental processes; they are not the principal focus of study. "Disasters bring serious disruption of the functioning of a community or a society involving widespread human, material, economic or environmental losses and impacts, which exceeds the ability of the affected community to cope using its own resources" (UNISDR, 2009).

"Everyday community social functions and social institutions are suddenly interrupted, many organizations cease operating or operate in a reduced manner, local officials are unable to complete their usual work tasks, most aid comes from distant areas, nonlocal mass media outlets cover the crisis, and high-ranking government officials and organizations become involved" (Quarantelli, 2008). The Gorkha earthquake in Nepal certainly meets all of the above characteristics. While vulnerability represents the social factors of disaster risk, hazard can be explained as the biophysical component of disaster risk. Disaster risk is typically considered a function of hazard and vulnerability.

"The Hindu Kush Himalayan region is highly vulnerable to earthquake and water-induced disasters. This fragile mountain region is under tremendous stress of climate change and landuse degradation that acceleratedflash flood, river-lineflood, erosion, wetmass movement during monsoon period and drought in non-monsoon period. Particular focus is required to understand the emerging risks as a result of climatic and land use changes and other a wide range of drivers contributing to increasing disaster risk in the region and to analyze the responses to disaster risks and disaster events" (Sahay, Gupta \& Menon 2016). The devastating Gorkha Earthquake of 7.6 Richter scale having the epicenter occurred near Barpak village of Gorkha district on 25 April 2015 had severely affected 14 districts and another 31 districts affected to varying extents (MoHA, 2015). Among the affected districts, most of the districts were mountainous where search and rescue operations were challenging due to the geographical feature which were remote, rural and hilly areas. It was basically because of the lack of road network, transport resources, and adverse weather condition.

Loss of life and damage to properties has been frequently observedin Nepal where climate change is considered a trigger for high mountain avalanches and lake outbursts. Nine major GLOF were recorded between 1935 and 1985 (Nyaupane \& Chhetri, 2009).

The outburst of the moraine-dammed Dig Tsho lake in 1985 in the Everest region, resulted in an extensive damage to tourist infrastructure and killed five people (Vuichard \& Zimmermann, 1987). Heavy snow during Fall 1995 caused deaths in many tourist locations, for example, 28 people were killed in Gokyo Valley in the Everest region in the avalanches of November 9 and 10. Similarly, seven people in Kanchanjunga and five in 
Annapurna region died because of avalanches. Landslide and debris flow of November 9 swept away houses and 15 people in Bagarchhap in Manang district. On 25 March, 2001, five individuals returning from the Annapurna Base Camp were swept away by debris flow induced by snow avalanche (MoHA, 2015).

Wildner \& Paal (2015), "Compared with hazard in an urban setting, the hazard in mountain areas may occur in an austere environment that presents additional challenges to the rescue team, such as geographical isolation, exposure to weather extremes, dangerous or difficult terrain, communication difficulties including limited or absent mobile network or radio connections, the need to rely on mountain rescue extrication techniques such as application of ropes or pulleys, limited human resources and equipment, and specific injuries and illness, for example accidental hypothermia".

Wikiwand (2020),"Mountain search and rescue refers to activities that occur in a mountainous environment, although the term is sometimes also used to apply to search and rescue in other wilderness environments. This tends to include mountains with technical rope access issues, snow, avalanches, ice, crevasses, glaciers, alpine environments and high altitudes. The difficult and remote nature of the terrain in which mountain rescue often occurs has resulted in the development of a number of specific pieces of equipment and techniques. Helicopters are often used to quickly extract casualties, and search dogs may be deployed to find a casualty".

NCDPS (2020), "Mountain Rescue Teams provide support to local emergency management or emergency services agencies by assisting in the location of missing persons, lost/overdue hikers, persons with cognitive impairments who have wandered from caretakers, or any individual that is reported as a lost or injured and whereabouts are unknown".

Pilemalm, Stenberg, \& Granberg (2013) indicate that "mountain rescue mostly occurs in remote areas where there are few communication tools, and away from public security force. It will take some time to get the conditions after receiving alarm. The terrain is complex, and it is hard to rescue. As the terrain in mountainous areas are full of gullies, the altitude is high and the slopes are steep, it is not easy to locate the correct site of incident and get to know the condition of the targets in a timely manner. At night, in particular, visibility is low. It's more difficult to find the people in dangers in the comparatively short time. This makes mountain rescue operations even more difficult.

At the same time, mountain incident sites are constantly accompanied with dangerous conditions such as explosions, rolling stones, avalanches, landslides, floods, and thunderstorms. Rescue team cannot accurately predict danger during the rescue operations. Freezing weather and cold have all made the rescue efforts difficult, and is a unique challenge to mountain emergency. Communication is also not smooth. It is hard to coordinate and command. It's hard to know the level of injury and the status of illness of the people in trap. Due to some complex factors at incident site, rescue team members can hardly contact the trapped people rescued, leading to delayed emergency response". 
Firth et al. (2008) published "a retrospective study on the mortality on Mt. Everest between 1921 and 2006. During the study period, 125 of 8030 climbers and 67 of 6108 Sherpas died, meaning 1.6 percent of all climbers and 1.1 percent of Sherpas climbing above base camp did not return home. The difficulty of rescues at extreme altitude undoubtedly increases mortality compared with lower altitude".

According to MoHA (2015), “Under Nepal Risk Reduction Consortium's five flagship priority areas, Flagship 2 is focused on Emergency Preparedness and Response. As part of its commitment to strengthening overall disaster preparedness and the disaster response system in Nepal, the Government has formulated a National Strategic Action Plan on Search and Rescue Capacity. It is aimed to be operational and applicable in the urban as well as rural setting in a scalable manner".

Kunwar (2016) provides a review on the concepts of safety, security and surety in tourism and the repercussions that risk, vulnerability, crisis, disaster, hazard, emergency and political turbulence can pose upon the industry. The article aims not just to prioritize the impacts of disasters on tourism but also aims to focus upon the issues of crisis management, disaster management and new marketing approaches for revival of tourism which comparatively are the less touched upon issues in the context of Nepal. The concept of tourism decision making is also studied here in the light of various theories. The article also discusses on the cultural dimension of tourist decision making and crisis management in relation with national culture and some theoretical orientation of crisis management in relevance to tourism.

Skinner (2018) highlighted on "the widespread international coverage of an insurance scam in Nepal that involves some helicopter companies, private hospitals and trekking agencies has hurt the country's image abroad, and impacted an industry just recovering from the 2015 earthquake. It is reported that some trek organizers, hospitals and helicopter companies in Nepal has been creating fake rescue of tourists in mountain region, or sometimes deliberately made them sick, so that they could collect and share insurance compensation".

"Insurance watchdog Traveler claimed its own investigations showed that $35 \%$ of the 1,600 helicopter rescues in Nepal this year were fraudulent, costing up to \$4 million" (Skinner, 2018). The company said it had intercepted and stopped 160 of the claims. The cost was serious enough for some international travel insurers to give the Nepal government till September to do something about it. Reacting to the ultimatum, the Ministry of Culture, Tourism and Civil Aviation formed a fact-finding committee to investigate how insurance companies had been defrauded with fake medical bills and fake rescues.

In the areas of mountain disaster and rescue mechanism in Nepal, the area is largely remained untouched. The various researchers studied about the Disaster and disaster management in Nepal but most of literatures have left the area of mountain disasters and rescue in Nepal. All the aspects prescribed and advocated by various intellectuals are not specific for Nepalese context. The research is focused to find out some actual scenario 
on the topic of mountain disasters and national rescue mechanism. In the disaster prone countries like Nepal, the research on mountain disasters and rescue is less than adequate. Therefore, further researches on this aspect are essential.

\section{Methodology}

The design of this paper is qualitative which is conducted in descriptive and analytical form. It is based on a review and examination of information gathered from a variety of secondary sources including Journal articles, books, government reports, policy papers, Acts and regulations, guidelines, websites, books and newspaper articles. Collected data is analyzed and interpreted in a meaningful way.

While exploring the issues of mountain disasters and rescue, it is tried to explain the disaster profile of Nepal in brief, types and nature of mountain disaster in Nepal, institutional and legal arrangements on mountain search and rescue. Data collected from secondary source has been analyzed by descriptive method. Different data found in literature has been used to find out the actual scenario of mountain disasters as well as rescue mechanism in Nepal. Facts and figures also has been used for better analysis of the study. The paper fully considers the ethical issues.

\section{Findings and discussion}

\section{Mountain disasters in Nepal}

The mountain region is highly vulnerable to flash floods, landslides, droughts, GLOFs, Avalanches and earthquakes, because of its unique geology, steep terrain, intense seasonal precipitation, and high seismicity, a truly multi-hazard environment (MoHA, 2019). The context of hazard and disaster is particularly relevant in a mountainous setting like the Himalayan region, where primary and secondary hazards are closely interrelated. Primary hazards may be geophysical or hydrometeorology (e.g., landslides), and trigger secondary hazards, such as landslide dams and subsequent outburst floods. For example, the 2015 Nepal earthquake resulted in landslides and avalanches. Some frequently occurring hazards in mountain regions are discussed here:

Landslide: Landslide is one of the very common natural hazards in the hilly and mountain region of Nepal. Both natural and human factors such as steep slopes, fragile geology, high intensity of rainfall, deforestation, unplanned human settlements are the major causes of landslide. The risk of landslide is further exacerbated by anthropogenic activities like improper land use, encroachment into vulnerable land slopes and unplanned development activities such as construction of roads and irrigation canals without proper protection measures in the vulnerable mountain belt. "The hilly districts of Nepallocated in the Siwalik, Mahabharat range, Mid-land, and also fore and higher Himalayas are more susceptible to landslide because of steep topography and fragile ecosystem" (Nepal DRR Portal, 2020) 
Glacial Lake Outburst Floods (GLOF): The impact of climate change on Himalayan glaciers has increasingly become the subject of public and scientific debate. "Climate change has been contributing to glacial retreat and expansion of lakes, thereby increasing Glacial Lake Outbrust Flood (GLOF) risk. Nepal has witnessed 24 GLOF events till date" (Bajracharya, 2010). "Glacial lakes in Nepal face a huge risk of Glacial Lake Outburst Flood due to the ongoing effects of climate change leading to the considerable amount of snow and glacier melt thus weakening the natural barriers holding these high altitude glacial lakes. About 14 such glacier lake outburst floods have been experienced between 1935 and 1991. A GLOF of 1985 caused a $10 \mathrm{~m}$ to $15 \mathrm{~m}$ high surge of water and debris to flood down the Bhote Koshi and Dudh Koshi Rivers for 90 kilometers which swept away a hydropower plant" (MoHA, 2015).

Earthquake: "Nepal on a regular interval witnesses earthquake along the major active faults in east-west alignment. Historical data and ongoing seismological studies have clearly indicated that the entire region of Nepal is prone to earthquake and it lies in the active seismic zone V. It has also pointed out that Siwalik, lesser Himalaya and frontal part of the Higher Himalaya are the most vulnerable zones. Historical data has shown that the country witnessed three major earthquakes in 20th century namely Bihar-Nepal earthquake (1934), Bajhang earthquake (1980) and Udayapur earthquake (1988). According to Global Report on Disaster Risk, Nepal ranks the 11th position in terms of earthquake risk as earthquakes have often occurred in Nepal"'(MoHA, 2019).

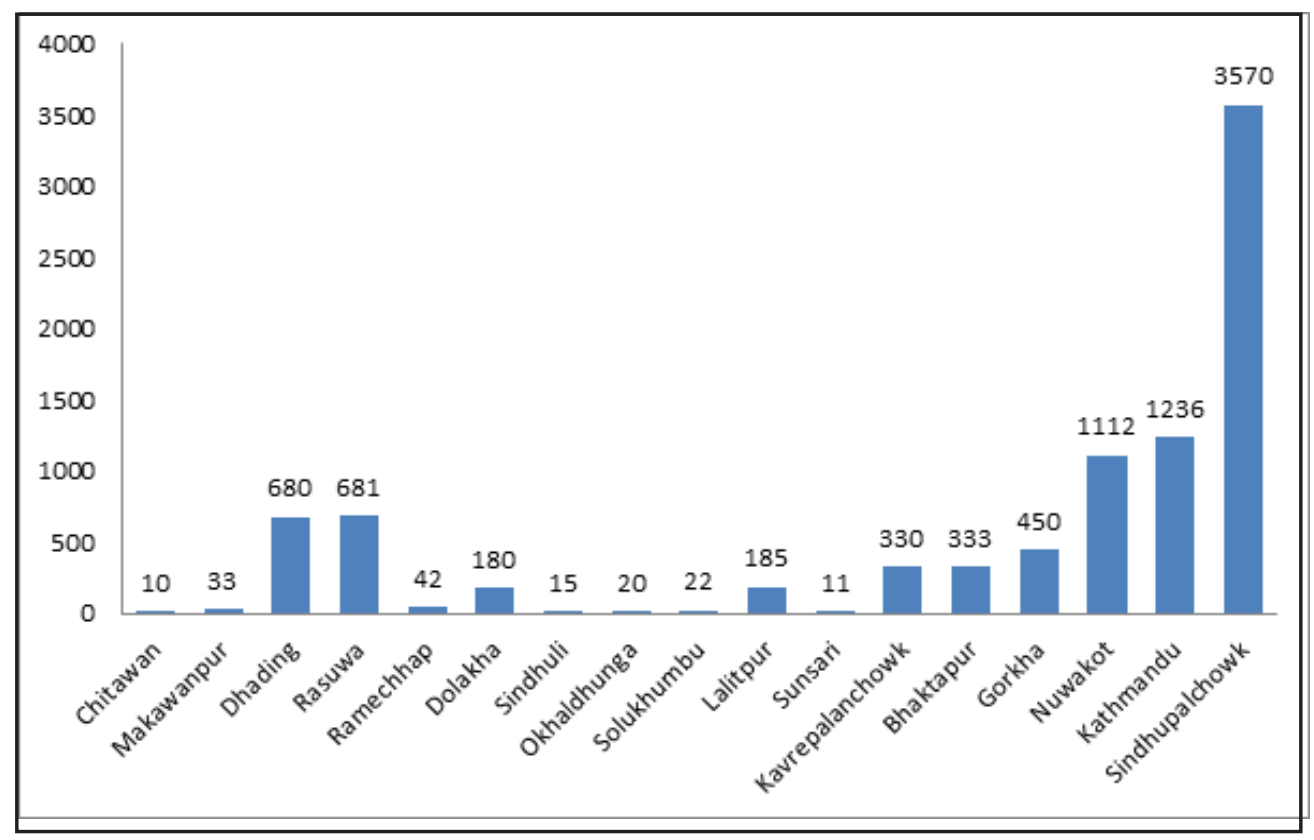

Figure 1: Fatalities due to Gorkha Earthquake 2015

Source: NEOC, 2020

Figure 1 compresses the table and shows the number of deaths due to the earthquake 2015. It only shows the badly affected districts. $\mathrm{X}$ and $\mathrm{Y}$ axis represents the name of 
district and number of deaths respectively. If we see closely; Sindhupalchowk, Solukhumbu, Dhading, Rasuwa, Ramechhap, Dolakha- which are either gateway or destination for High Altitude were badly affected. The physical damage and collapsed buildings, hotel and infrastructure had affected the transaction of tourists.

Avalanche: "Avalanches are a rapid movement of snow and debris flowing down through the slope or flanks of mountains. It can be triggered by natural factors like slopes, thickness of snow or human activity. The high mountainous region having the rugged and steep slopes topographically is susceptible to avalanche. The northern part of Nepal is covered with high mountains where avalanche is very common and sometimes it claims the life of human being as well" (MoHA, 2019).

Table 1: Avalanches and its impact on human in Nepal (from 2012-2019)

\begin{tabular}{|c|c|c|c|c|}
\hline District & Incident Date & Total Death & Missing People & Injured \\
\hline Gorkha & $9 / 23 / 2012$ & 9 & 3 & 13 \\
\hline Darchula & $1 / 18 / 2013$ & 0 & 0 & 0 \\
\hline Dolpa & $2 / 12 / 2013$ & 2 & 0 & 0 \\
\hline Bajhang & $5 / 17 / 2013$ & 0 & 7 & 0 \\
\hline Bajhang & $6 / 21 / 2013$ & 1 & 0 & 0 \\
\hline Manang & $9 / 29 / 2013$ & 2 & 1 & 0 \\
\hline Solukhumbu & $10 / 16 / 2013$ & 3 & 0 & 0 \\
\hline Solukhumbu & $4 / 18 / 2014$ & 13 & 3 & 7 \\
\hline Taplejung & $5 / 20 / 2014$ & 0 & 3 & 0 \\
\hline Manang & $1 / 3 / 2015$ & 1 & 0 & 1 \\
\hline Gorkha & $3 / 1 / 2015$ & 0 & 0 & 0 \\
\hline Jumla & $3 / 4 / 2015$ & 0 & 1 & 1 \\
\hline Dolpa & $3 / 12 / 2017$ & 1 & 1 & 0 \\
\hline Dhading & $1 / 27 / 2019$ & 2 & 0 & 0 \\
\hline Dolpa & $2 / 8 / 2019$ & 1 & 0 & 0 \\
\hline Manang & $3 / 8 / 2019$ & 2 & 0 & 0 \\
\hline Dolpa & $3 / 31 / 2019$ & 3 & 0 & 0 \\
\hline Rukum East & $5 / 2 / 2019$ & 0 & 0 & 1 \\
\hline Dolpa & $6 / 5 / 2019$ & 0 & 1 & 0 \\
\hline Total & & 40 & 20 & 23 \\
\hline
\end{tabular}

Source: NEOC, 2020 
The table 1 presents the impacts of avalanches in mountain region of Nepal from 2012 to 2019 . We can trace on remarkable fact that from the above data, $48.19 \%$ of total victims face the spontaneous death, $24 \%$ go missing and $27 \%$ get badly injured due to the avalanche.

Acute mountain sickness or High Altitude Sickness: "Acute Mountain Sickness is a particularly important medical consideration while trekking in high Himalayas of Nepal. High altitude sickness means the effect of altitude on those who ascend too rapidly to elevations above 3000 to $10,000 \mathrm{ft}$. The occurrence of AMS is dependent upon the elevation, the rate of ascent, and individual susceptibility" (Guide in Himalaya, 2020).

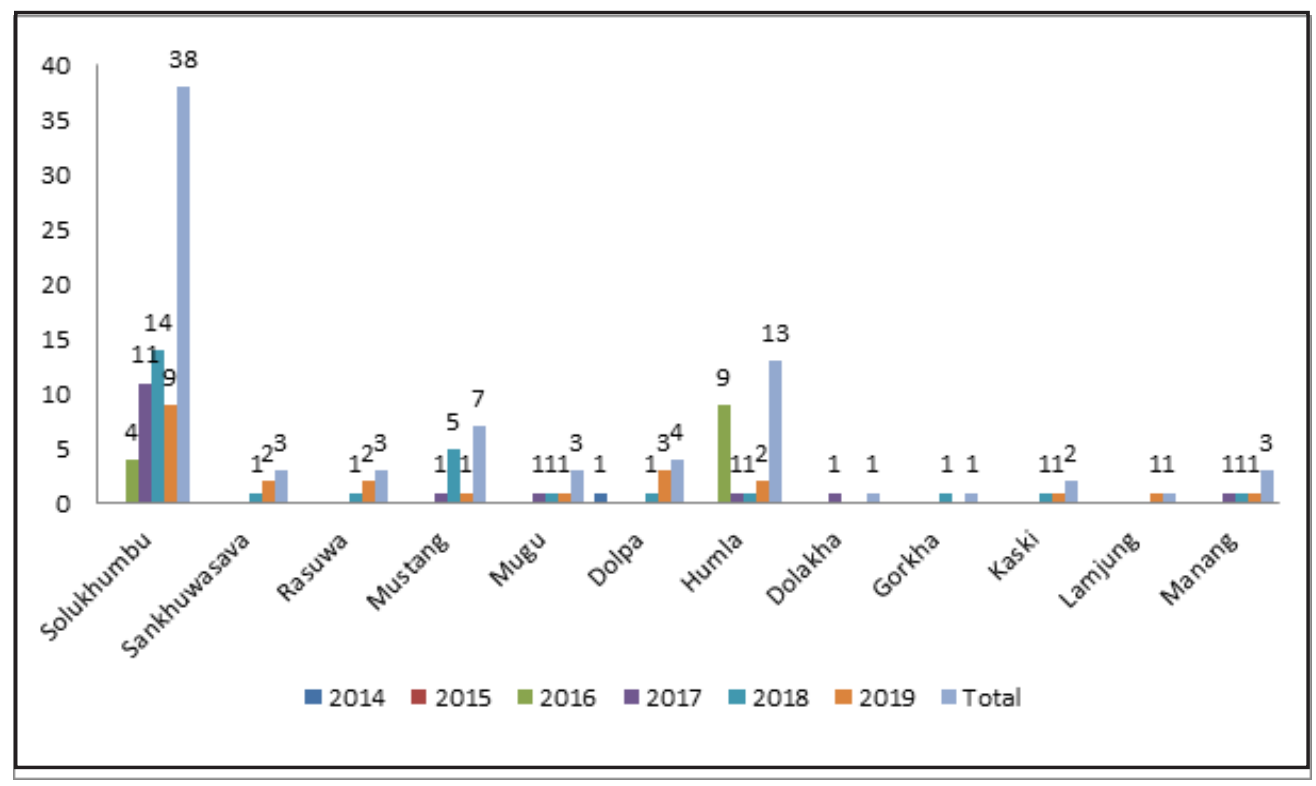

Figure 2: Deaths due to Acute Mountain Sickness (2014-2019)

Source: NEOC, 2020

The above graph shows the number of deaths due to the high altitude sickness. Solukhumbu has highest number of cases because it lies around the Khumbu region, which is regarded as one of the most visit places in Nepal and the transaction of tourist is always high. Lamjung, Manang, Mustang, Kaski are in Annapurna Conservation area, the flow of inland and foreign tourist is very high. It has several touristic destinations. That's why the frequency of death is significant. Year 2015 and 2016 have very low number of casualties, might be because of less flow of tourist, because there was mega earthquake in 2015 .

Aircraft Accidents in Mountain Region: Having a mountainous terrain, Nepal has sketchy records when it comes to aircraft accidents. Most of the aircraft accidents were took place in the mountain regions and rescuers faced many challenges due to the difficult terrain and adverse weather. Regmi, Kitada, Dudhiya \& Maharjan (2017) indicate that "The development of hazardous weather over the region may be attributed to a previously unanticipated large-scale easterly gravity current over the middle hills of the Nepal 
Himalaya. The gravity current originated from the central high Himalayan mountainous region located northeast of the Kathmandu valley and traveled more than $200 \mathrm{~km}$, reaching the foothills of the western Nepal Himalaya".

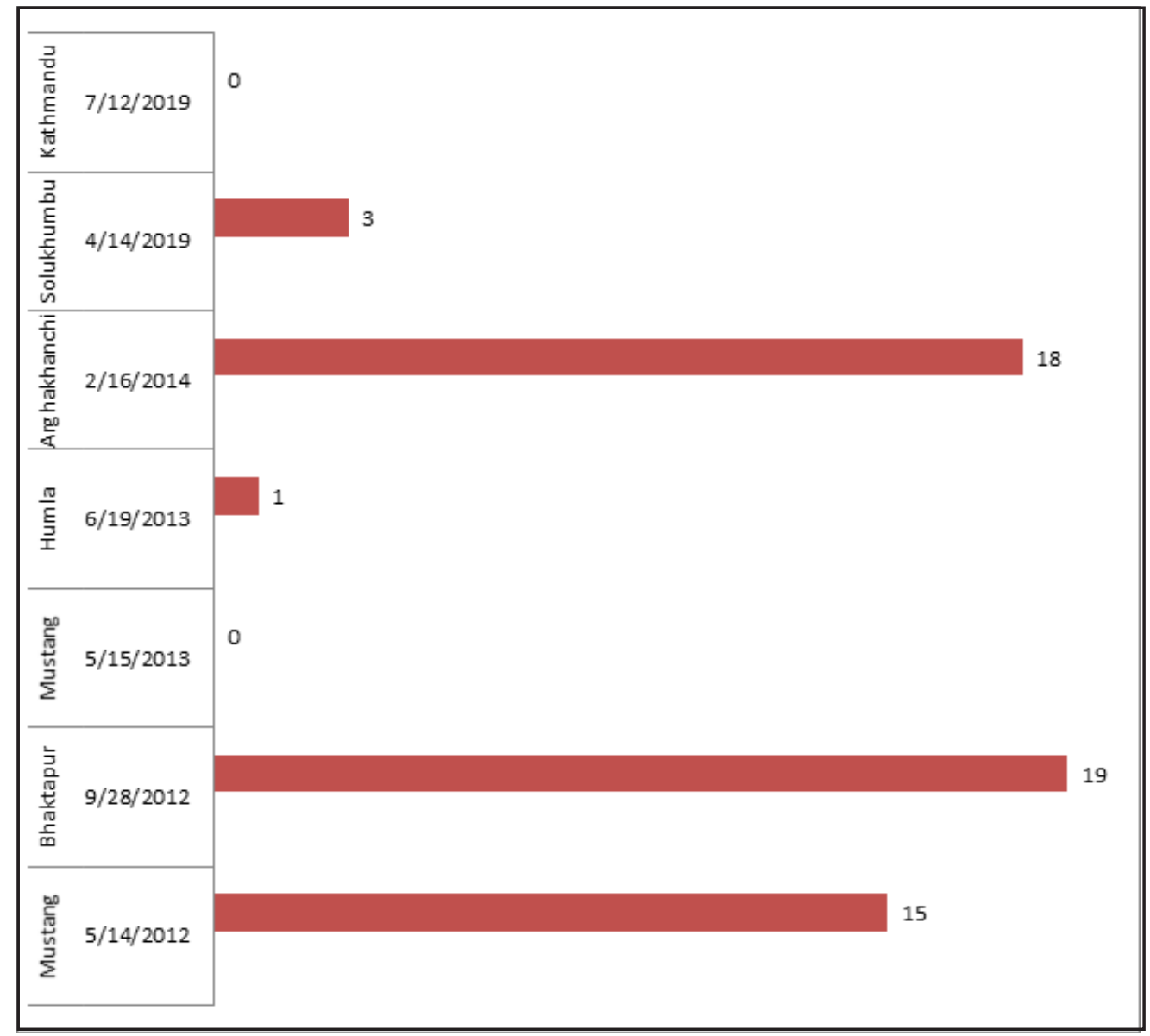

Figure 3: Aircraft accidents in mountain region

Source: MoHA, 2019

In figure 3, The horizontal graph gives the graphical presentation. The OX axis and OY axis represents the number of deaths and Year \& Districts respectively. Human error as well as the difficult topography, bad weather and the practice of flying old aircraft for a long time have also their role in the increasing number of air crashes.

\section{Mountain Disaster Rescue in Context of Nepal}

Mountain Rescue relates to SAR operations specifically in rugged and mountainous terrain. Qualified and experienced trekkers/mountaineers do this type of search, aided by ground navigation and air support. These are among the most challenging of SAR operation.

Over the past several years, dedicated personnel at security forces and in partnership with some NGOs, Government of Nepal has developed minimal Search and Rescue 
capacity in the country. Personnel from the Nepal Army, Nepal Police and APF, Likewise, the units of all security forces are located at all districts but most of them are located at the district headquarters. Besides security agencies, private helicopter companies and volunteer agencies are also conducting mountain search and rescue operations.

\section{Legal Arrangements}

In Nepal, Disaster Risk Reduction and Management Act, 2017 includes all phases of disaster management activities. It provides the basis for the operation of Search and Rescue activities for disaster response. Search and Rescue activities for disaster response are also covered by the DRRM Regulations 2019, Local Government Operations Act, 2017, National Policy on Disaster Risk Reduction, 2018, National Strategic Action Plan on Disaster Risk Reduction 2018-2030, National Strategic Action Plan on Search and Rescue, 2014 and National Disaster Response Framework, 2019 etc. Among them, Tourist Search, Rescue, Medication and Monitoring Guidelines 2018 is focused on the rescue of tourists from mountain hazards.

Tourist Search, Rescue, Medication and Monitoring Guidelines 2018: Major provisions Ministry of Culture, Tourism and Civil Aviation has framed the 'Tourist Search, Rescue, Medication and Monitoring Guidelines- 2018' to coordinate and conduct tourist search and rescue operations effectively. The guideline is implemented with the goal of systematizing the searchandrescue oftouristsincaseofnaturaldisastersandotherincidents. The purpose of the guideline is also to lessen the impact of such disasters as far as possible.

According to the guideline, in case of search and rescue of tourist, the concerned agency (the company granted license from the department that causes to operate trekking, expedition, rafting or such other adventure activities) shall have the primary obligation to search and rescue. If the agency itself cannot carry out the search and rescue operation, it should notify the Tourist Police and the Department of Tourism at the earliest along with the name, nationality, passport number and other details of the tourist caught up in disaster. The guideline also has provision of a Tourist SAR Directorate Committee (MoCTCA, 2018).

Table 2: Tourist Search and Rescue Directorate Committee

\begin{tabular}{|c|c|c|c|}
\hline S.N. & Agency & Responsibility & Reference \\
\hline 1. & Director General, DoT & Coordinator & \\
\hline 2. & Representative, MoHA & Member & Gazetted II \\
\hline 3. & Representative, MoHP & Member & Gazetted II \\
\hline 4. & Representative, Nepal Tourism Board & Member & Director \\
\hline 5. & Representative Civil Aviation Authority & Member & Dy. Director \\
\hline 6. & President, Nepal Mountaineering Association & Member & \\
\hline 7. & President, Himalayan Rescue Association. & Member & \\
\hline 8. & Head, Tourist Police & Member & \\
\hline 9. & Director, Mountaineering Section, DoT & Member- Secretary & \\
\hline
\end{tabular}

Source: MoCTCA, 2018 


\section{Institutional Mechanisms}

\section{Ministry of Home Affairs}

MoHA is playing a coordinating role in disaster management and disaster response activities in Nepal. Under coordination of MoHA, other thematic ministries of the government, commissions, and departments, national and international organizations are carrying out disaster response-related activities in the country. The Executive committee chaired by the Minister of Home Affairsis the authority to formulate policy and plans for disaster response and provide necessary guidelines. Under Executive Committee, NDRRMA is established (MoHA, 2017). NEOC is working as a central coordinating body to collect and disseminate information in time of a disaster and provide disaster response and humanitarian assistance. NEOC has also been authorized to assess the institutional capacity of various bodies and in time of an emergency disaster response work in coordination with disaster focal points at various ministries/commission and departments.

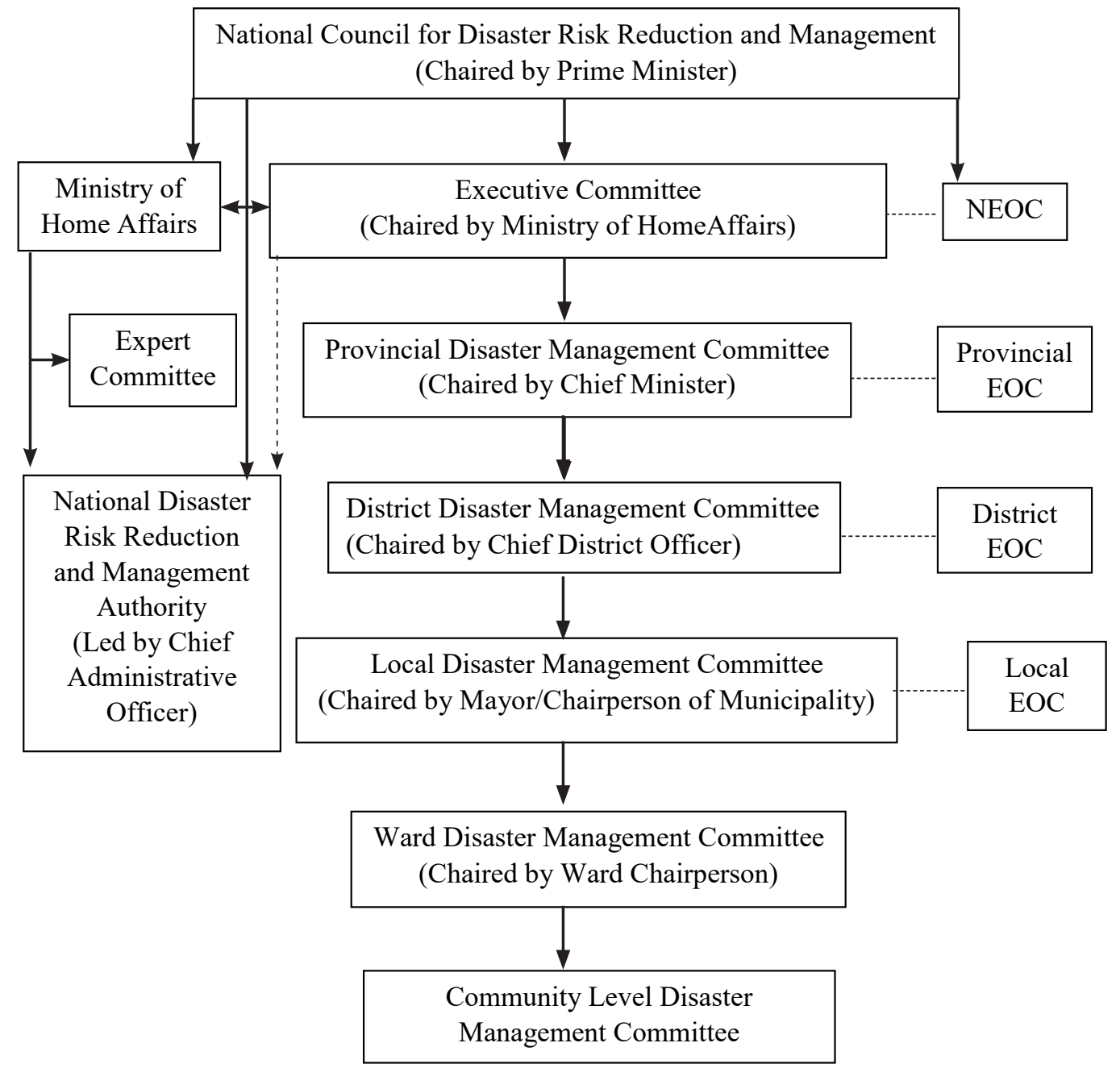

Figure 4: Institutional Framework of Disaster Risk Management in Nepal

Source: Disaster Risk Reduction and Management Act, 2017 
Institutional Framework of Disaster Risk Management in Nepal is shown in figure 4, based on the Disaster Risk Reduction and Management Act, 2017. It covers all three tiers of the governments, from federal to local level, and other stakeholders.

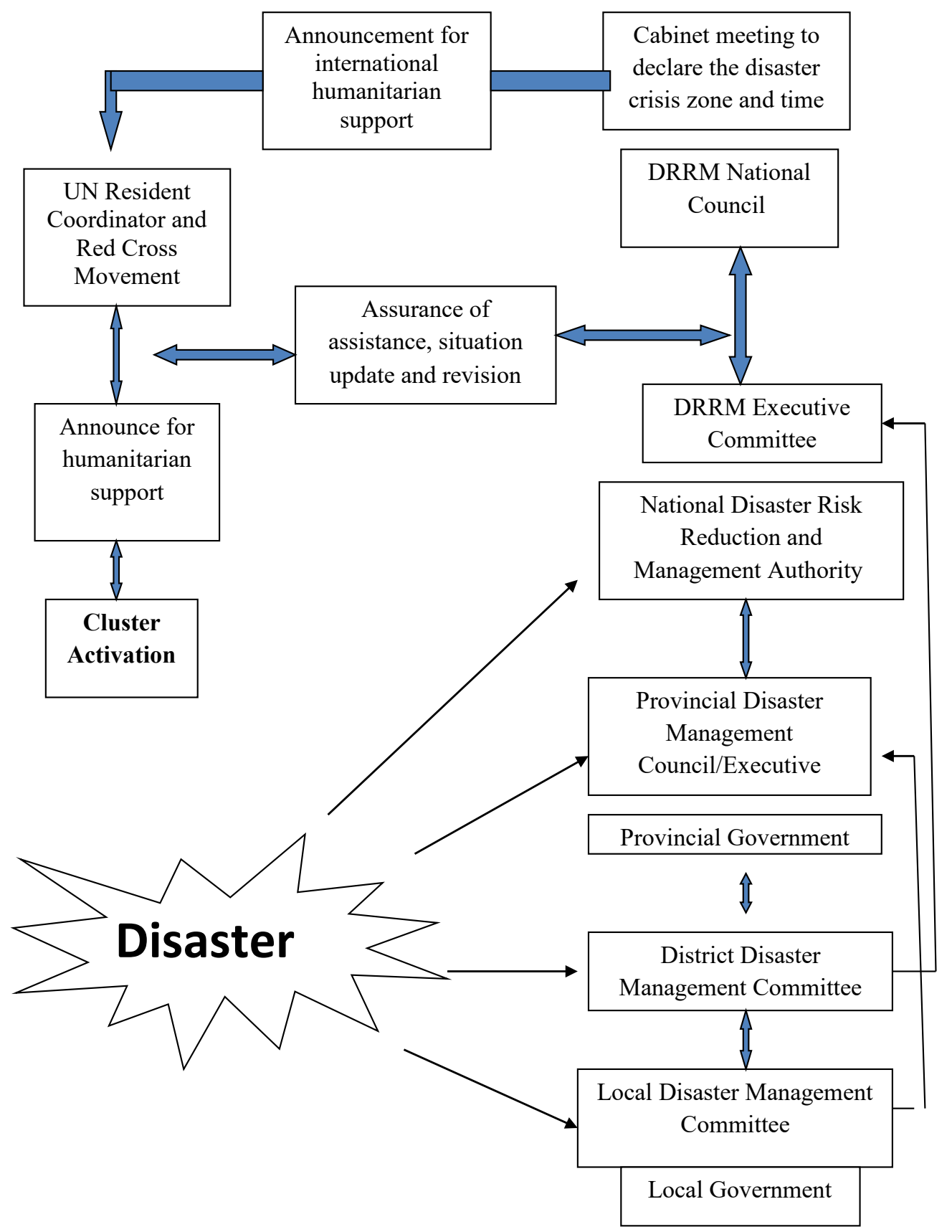

Figure 5: National Disaster Response Framework

Source: Disaster Risk Reduction and Management Act, 2017 
Figure 5 illustrates the government structure on disaster risk reduction, response framework and procedures during disasters of large scales which are equally applicable for the mountain rescue operations.

Nepali Army: Nepali Army (NA) has been playing the role of the major response actor in disaster management since the past and on many occasions also an active leading role in times of emergency response. The Government of Nepal has given NA the responsibility of the first response actor in Search and Rescue (SAR) operations during a disaster NA has an organized and disciplined structure, its own aviation service for air rescue, communication system, transport system, health services and the capacity to conduct basic SAR activities. Dedicated units for disaster search and rescue: Nepal army has Directorate of Disaster Management under the Director General of Military Operations. Under the directorate there are two disaster management battalions fully committed in disaster management role. No. 1 Disaster Management battalion is in Sundarijal, Kathmandu and No. 2 Disaster Management Battalion is located in Rasauli, Chitawan. Recently Disaster Management Training School is established to conduct different level trainings in disaster and emergency management. Besides that Nepal Army Aviation, Army Medical Corps, Combat Engineers, Signals and Ranger and Special Forces are other components of the Nepal Army playing crucial role in disaster response operations. Infantry Units deployed in all districts of Nepal are also committed to support local governments on humanitarian assistance and disaster response operations. Two MI 17 helicopters are placed on active service since 2015 for Disaster rescue operations.High Altitude and Mountain Warfare School (HAMWS) is conducting mountain search and rescue operations.Special force units under No. 10 Brigade (Special Forces) are also mobilizing for mountain SAR Operations (DMHA, 2017).

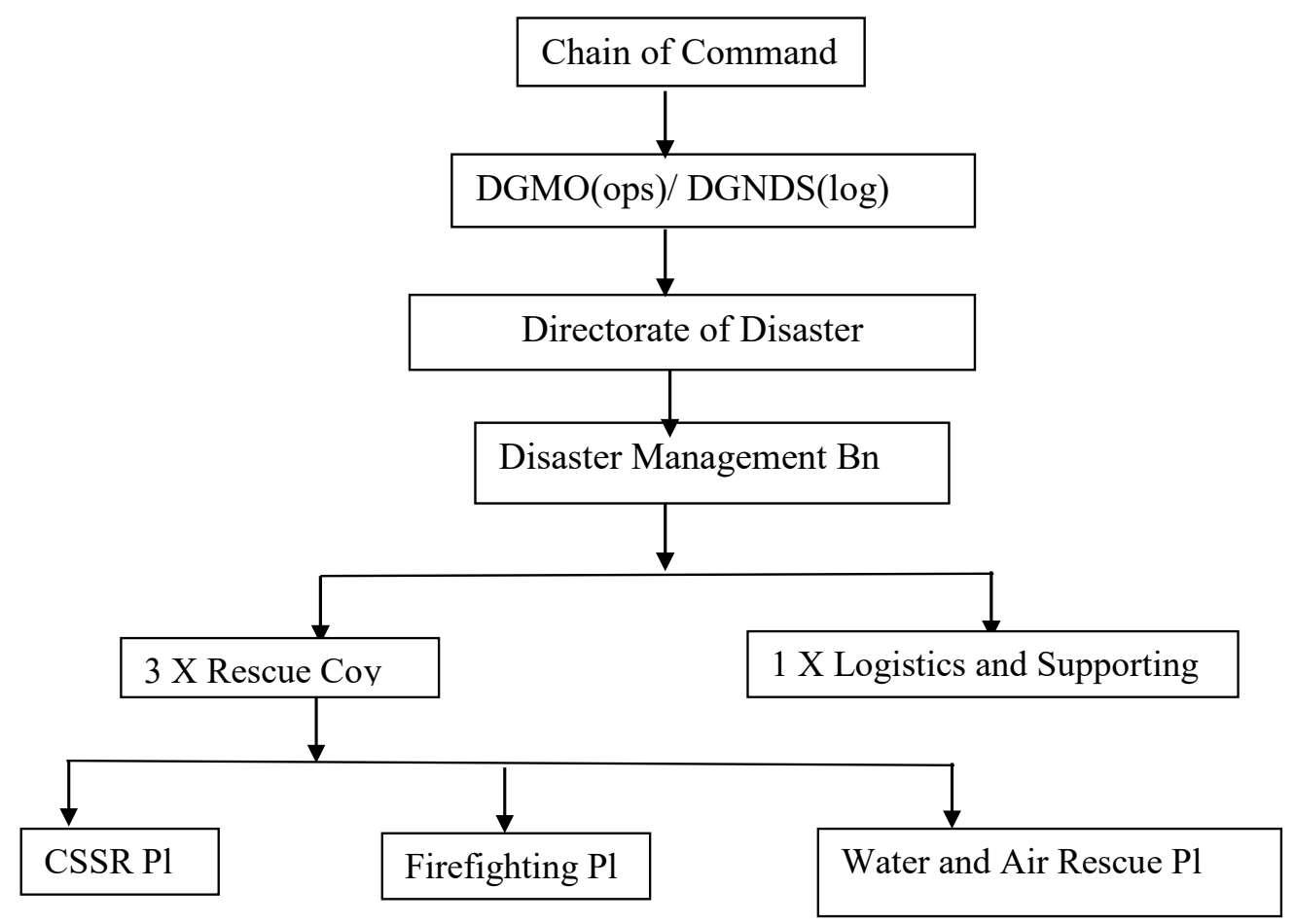

Figure 6: Command Structure of NA Disaster Management.

Source: Directorate of Disaster Management, 2020 


\section{Armed Police Force, Nepal}

The Armed Police Force, Nepal (APF, Nepal) was established as per the Armed Police Force Act, 2058. Among its roles, the significant and mandated task is to support in the search, rescue and relief management of the victims of disaster and epidemic (APF, Nepal, 2058).

Dedicated units for disaster search and rescue: In 2011, Disaster Management Training Center, now Disaster Management Training School (DMTS) was established in Kurintar, Chitwan. The objective of establishing the disaster management training center is to produce skilled and professional human resource for search and rescue \& to enhance the capacity of APF, Nepal in disaster rescue operations as well as other fields of disaster risk reduction. After restructure of the organization, now APF, Nepal has its presence in all districts of Nepal. It has also positioned its SAR teams in all Provinces under each Brigades with basic rescue equipments which are conducting SAR operations in mountain regions also. In 2019, GoN has approved the establishment of High Altitude and Mountain Rescue Training School. It is establish in Manang district. The human resource required for the school has recently approved. The School is aimed to train APF personnel for high altitude and mountain rescue operations.

Table 3: Units of APF, Nepal in A Category remote/mountain districts.

\begin{tabular}{|c|c|c|c|}
\hline S.N. & District & Unit & Approved no. of personnel \\
\hline 1. & Taplejung & No. 1 Coy & 160 \\
\hline 2. & Sankhuwasabha & No. 4 Coy & 160 \\
\hline 3. & Solukhumbu & Dependent Coy & 141 \\
\hline 4. & Dolakha & No. 18 Coy & 160 \\
\hline 5. & Dhading & Dependent Coy & 141 \\
\hline 6. & Gorkha & No. 29 Coy & 160 \\
\hline 7. & Baglung & Dependent Coy & 141 \\
\hline 8. & Manang & No. 32 Coy & 160 \\
\hline 9. & Mustang & No. 33 Coy & 160 \\
\hline 10. & Humla & No. 44 Coy & 160 \\
\hline 11. & Mugu & No. 45 Coy & 160 \\
\hline 12. & Dolpa & No. 46 Coy & 160 \\
\hline 13. & Kalikot & Dependent Coy & 160 \\
\hline 14. & Jumla & No. $33 \mathrm{Bn}$ & 621 \\
\hline 15. & Jajarkot & Dependent Coy & 141 \\
\hline 16. & Rukum East & Dependent Coy & 141 \\
\hline 17. & Rukum West & No. 47 Coy & 160 \\
\hline 18. & Rolpa & Dependent Coy & 141 \\
\hline 19. & Ahham & No. 49 Coy & 160 \\
\hline 20. & Bajhang & Dependent Coy & 141 \\
\hline 21. & Bajura & Dependent Coy & 141 \\
\hline 22. & Darchula & No. 44 Bn \& No. 50 Coy & $621 \& 160$ \\
\hline
\end{tabular}


Source: APF, Nepal Operations and Border Security Department, 2020

Table 3 illustrates the deployment of APF, Nepal units in 'A' Category remote mountain districts with approved strength. They have basic capacity to carry out ground and light rescue operations.

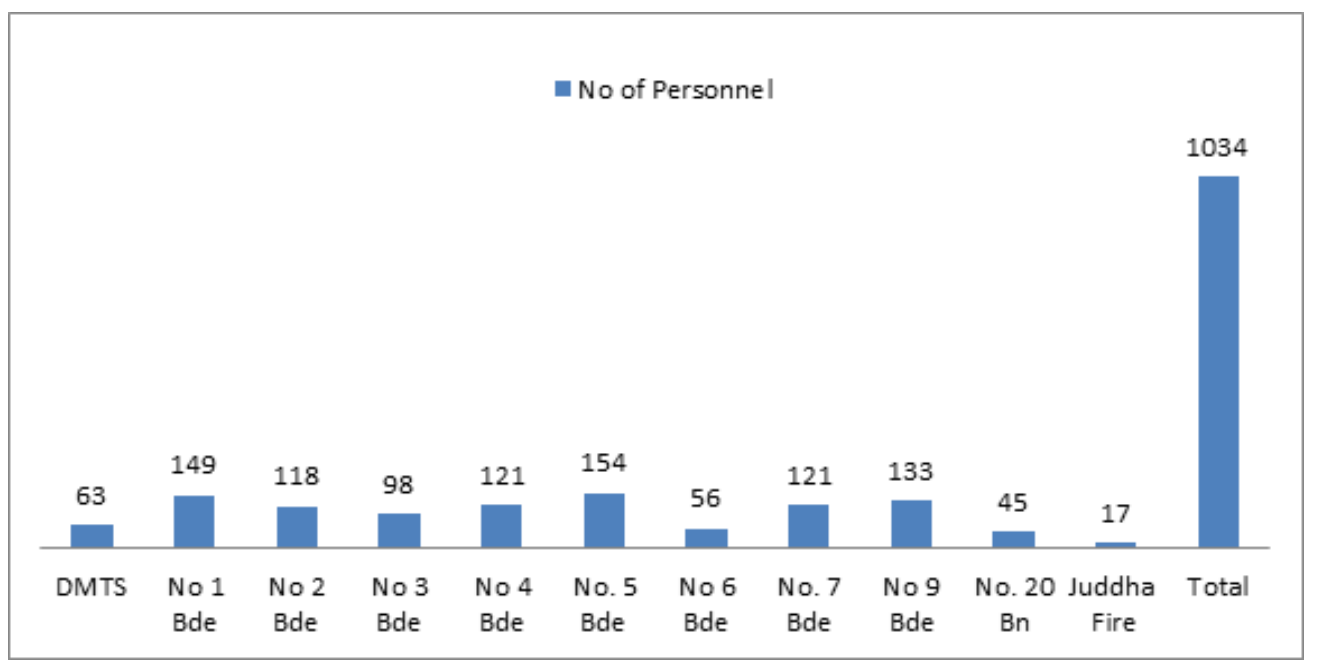

Figure7: Deployment of APF SAR teams in different units.

Source: APF, Nepal Disaster Management Section, 2020

Figure 7indicates the deployment of SAR teams of APF, Nepal in different units and areas of Nepal, as of 15 May, 2020.These SAR teams are trained from DMTS, Kurintar and they have basic skills of CSSR, Rope rescue, MFR, Water Rescue etc.

Table 4: Total number of Rescue Equipment Set in APF, Nepal

\begin{tabular}{|c|c|c|}
\hline S.N. & Equipment Type & No. of Set \\
\hline 1. & CSSR & 56 \\
\hline 2. & Fire Fighting & 32 \\
\hline 3. & Rope Rescue & 26 \\
\hline 4. & Deep Diving & 25 \\
\hline 5. & Rescue Raft & 25 \\
\hline 6. & MFR & 4 \\
\hline 7. & Dead Body Management & 4 \\
\hline 8. & Life Detecting Equipment & 4 \\
\hline 9. & Heavy Equipment & 13 \\
\hline
\end{tabular}

Source: APF, Nepal Disaster Management Section, 2020 
Table4 illustrates the available rescue equipment sets in APF, Nepal which are basic in nature and suitable for light to medium level SAR operations.

Nepal Police: Disaster Management is one of the major responsibilities that Nepal Police (NP) is mandated to work for. The Police act and Police regulation regarding the duty and responsibility state that every police unit has to be mobilized for disaster management(NepalPolice,2012). Othernationallawsand policiesalsoincludetheroleofNepal Police in search and rescue operations. NP has been traditionally performing the role of the first responder in time of an emergency. It has its presence all over the Nepal including mountain region.

Dedicated units for disaster search and rescue: Disaster Management Division was established as specialized police unit to work in the area of SAR operations on 2069/10/21 having a Senior Superintendent of Police as an in-charge. There are eight SAR police units, including Regional Police Disaster Management Task Force with total 1322 manpower in Nepal Police with the mandate to work solely in the field of Disaster Risk ReductionandManagement(NepalPolice,2020). Therearenospecializedmountainsearchand rescue units in Nepal Police, though Tourist police unit at Nepal Tourism Board deals with operations to tourist search and rescue activities.

Table 5: Disaster Management Units of Nepal Police

\begin{tabular}{|c|c|}
\hline Name of Office & District/Location \\
\hline Disaster Management Division & Kathmandu/samakhushi \\
\hline 1 No. State Disaster Management Company & Jhapa/chandragadhi \\
\hline 2 No. State Disaster Management Company & Parsa/Birgunj \\
\hline 3 No. State Disaster Management Company & Makwanpur/Hetauda \\
\hline Gandaki State Disaster Management Company & Baglung \\
\hline 5 No. State Disaster Management Company & Dang/Tulshipur \\
\hline Karnali State Disaster Management Company & Jumla \\
\hline Far-West State Disaster Management Company & Kanchanpur \\
\hline
\end{tabular}

Source: Nepal Police Disaster Management Division, 2020

Private/ Civil Agencies: Privately owned helicopter companies and volunteer organizations like Himalayan Rescue Association are mainly working for the mountain search and rescue. The Himalayan Rescue Association has been contributing to prevent deaths from Acute Mountain Sickness Currently it runs aid posts in the Solukhumbu and Manang. It also mobilizes volunteer doctors to provide medical services to the trekkers (HRA, 2020).

MoCTCA (2018), In 2018, 3 helicopter companies, 4 hospitals and 8 trekking organization charged for 'fake rescue case' by an investigating committee formed by the government. The committee found that there had been 1,300 helicopter rescues in the first five months of 2018, costing insurers more than $\$ 6.5$ million. These cases indicate that the private 
agencies are more focused on profit making by fake insurance claims.

According to Tourist Search, Rescue, Medication and Monitoring Guidelines 2018, helicopter companies, travel and tour operators, hospitals and insurance companies need to submit details of rescue flights, medical treatment and insurance bills to the Tourist Search and Rescue Committee, Tourist Police and Department of Tourism. Currently, 10helicoptercompaniesareoperatinginNepal.Thesecompanieshave 33 helicopters of different capacities. All these helicopters are of 4-6 seats capacity (Avaiationnepal, 2020).

Table 6: List of Private Helicopter companies with air assets

\begin{tabular}{|c|c|c|}
\hline S.N. & Company Name & No. of Helicopters \\
\hline 1. & Air Dynasty owns & 5 \\
\hline 2. & Shree Airlines owns & 7 \\
\hline 3. & Simrik Air owns & 4 \\
\hline 4. & Prabhu helicopter owns & 5 \\
\hline 5. & Summit helicopter owns & 2 \\
\hline 6. & Heli Everest & 2 \\
\hline 7. & Manang Air & 2 \\
\hline 8. & Mountain helicopters & 2 \\
\hline 9. & Kailash helicopters & 1 \\
\hline 10. & Altitude Air & \\
\hline
\end{tabular}

Source: Aviationnepal, 2020

Table 6 lists the name of private helicopter companies and air assets owned by them, as of 2019 .

\section{Conclusions}

Located in the central of the Himalaya range, Nepal is one of the most disaster-prone countries in the world due to its topography and climatic condition. Mountains are also attractive tourist destinations. Every year thousands of tourists flock to the mountains for recreational activities. Associated with these activities and various hazards, the mountain region is becoming a hotspot for disasters that claim loss of life, property, and environment. ThemountainregionisauniquelychallengingenvironmentforSearchandRescue operations; it differs from any other region in Nepal, and it requires a similarly unique approach for SAR operations.

There are several categories of SAR, depending primarily on geography or terrain, but the general concept is the same- emergency teams are dispatched to locate, assist, and rescue people in crises. Search and Rescue begins once the type of crisis or area of distress is identified. To carry out effective and efficient search and rescue operations, a thorough understanding, the type and nature of crises is crucial. Further, search and rescue is also 
an integral part of overall crisis management, Search, rescue, and evacuation in mountain regions are among the most challenging tasks. There are few SAR units in the mountain region in comparison to other areas. Long distances increase response times and make logistics and maintenance both more expensive and more complicated. Some legal and institutional arrangements are set up for the mountain search and rescue but they are not sufficient and effective.

Hence utmost skill, training, and expertise are needed for those responsible for the task. This is not the responsibility of the Government alone and requires a multi-sectoral effort. It will lead to more lives saved while facing future disasters. In this regard, Nepal should increase its capacity and adopt models and good practices from other countries that are the pioneers of mountain search and rescue. Specialized training based on international standards should be conducted, that is conducive to Nepal's condition and environment on a long-term basis. The roles of the rescue agencies must be made explicit and should not be left ambiguous to avoid confusion and unethical acts like a fake rescue. Once responsibilities are assigned, suitable organizational changes should be effected and adequate resources must be allocated.

\section{References}

APF, Nepal. (2058). Armed Police Force Act, 2058. Kathmandu: Government of Nepal

Aviationnepal. (2018). Separate helicopter terminal to be built at TIA. Retrieved 15 September, 2020, from https:/www.aviationnepal.com/separate-helicopterterminal-to-be-built-at-tia/.

Bajracharya, S.R. (2010). Glacial Lake Outburst Flood Disaster Risk Reduction Activities in Nepal. International Journal of Erosion Control Engineering. 3 (1).

DDM. (2020). Chain of Command of NA Disaster Management. Kathmandu: Nepali Army

DMHA. (2017). Nepal Disaster Management Reference Handbook. HAWAII: DMHA.

Dynes, R., \& Quarantelli, E. L. (1980). Helping behavior in large-scale disasters. In D. H. Smith, \& J. Macaulay (Eds.), Participation in social and political activities. San Francisco, CA: Jossey-Bass.

Firth, P.G. et al. (2008). Mortality on Mount Everest, 1921-2006: a descriptive study. Journal of Management Studies, 25, 373-385.

GoN (2017). Disaster Risk Reduction and Management Act, 2017. Kathmandu: Government of Nepal.

Guide in Himalaya. (2020). What is Acute Mountain Sickness. Retrieved September 14, html.

HRA. (2020). Introduction. Retrieved 16 September, 2020 from http://himalayanrescue. org.np/about-us/

John, W. (1980). Disasters: the anatomy of environmental hazards. Harmondsworth: Penguin. 
Kunwar, R. R. (2016). Tourism Crisis and Disaster Management. The Gaze Journal of Tourism and Hospitality, 7, 1-36.

MoCTCA. (2019). Nepal Tourism Statistics. Kathmandu: Government of Nepal.

MoCTCA. (2018). Tourist Search, Rescue, Medication and Monitoring Guidelines 2018. Kathmandu: Government of Nepal

MoHA. (2015). Nepal Disaster Report, 2015. Kathmandu: Government of Nepal.

MoHA. (2017). Nepal Disaster Report, 2017. Kathmandu: Government of Nepal.

MoHA. (2019). Nepal Disaster Report, 2019. Kathmandu: Government of Nepal.

NCDPS.(2020). Mountain Rescue. Retrieved May 16, 2020, from https://www.ncdps.gov/ our-organization/emergency-management/emoperations/em-resources/search-rescue/mountain-rescue.

NEOC. (2020). Disaster Database. Kathmandu: Ministry of Home Affairs.

Nepal DRR Portal. (2020). Risk Profile of Nepal. Retrieved August 25, 2020, from http:// www.drrportal.gov.np/risk-profile-of-nepal.

Nepal Police. (2012). Police Act, 2012. Kathmandu: Government of Nepal.

Nepal Police. (2020). Disaster Management Division. Retrieved September 15, 2020, from https://www.nepalpolice.gov.np/index.php/disaster-management-divisions.

Nyaupane, G. P. \& Chhetri, N. (2009). Vulnerability to climate change of nature-based tourism in the Nepalese Himalayas. Tourism Geographies, 15 (5), 5.

Oliver, J. (1980). The disaster potential. North Queensland: James Cook University.

Pilemalm, S., Stenberg, R., \& Granberg, T. A. (2013). Emergency Response in Rural Areas. International Journal of Information Systems for Crisis Response and Management, 5(2), 19-31.

Quarantelli, E.L. (1988). Disaster crisis management: A summary of research findings. Journal of Management Studies, 25(4), 373-385.

Regmi, R. P., T. Kitada, J. Dudhia, and S. Maharjan. (2017). Large-Scale Gravity Current over the Middle Hills of the Nepal Himalaya: Implications for Aircraft Accidents. J. Appl. Meteor. Climatol, 56, 371-390.

Sahay B., Gupta S., Menon V. (2016). Managing Humanitarian Logistics. Springer Proceedings in Business and Economics. New Delhi: Springer.

Skinner, R. (2018, September, 21). Heli rescue fraud tarnishes Nepal's image. Nepali Times, Retrieved from https://www.nepalitimes.com/banner/heli-rescue-fraudtarnishes-nepals-image/ 
UNISDR. (2009). UNISDR Terminology on Disaster Risk Reduction. Geneva: United Nations International Strategy for Disaster Risk Reduction.

UNISDR. (2015). Sendai framework for disaster risk management 2015-2030. Geneva: United Nations Office for Disaster risk management.

Vuichard, D. \& Zimmermann, M. (1987). The 1985 catastrophic drainage of a morainedammed lake, Khumbu Himal, Nepal: Causes and consequences. Kathmandu: Mountain Research \& Development.

Wikiwand. (2020). Mountain Rescue. Retrieved May 15, 2020, from https://www.wiki wand.com/en/Mountain_rescue.

Wildner, M., \& Paal P. (2015). A large-scale accident in Alpine terrain. Med Klin Intensivmed Notfmed. 110, 21-26. 